This article was downloaded by: [University of Calgary] On: 02 February 2015, At: 16:45

Publisher: Routledge

Informa Ltd Registered in England and Wales Registered Number: 1072954 Registered office: Mortimer House, 37-41 Mortimer Street, London W1T 3J H, UK

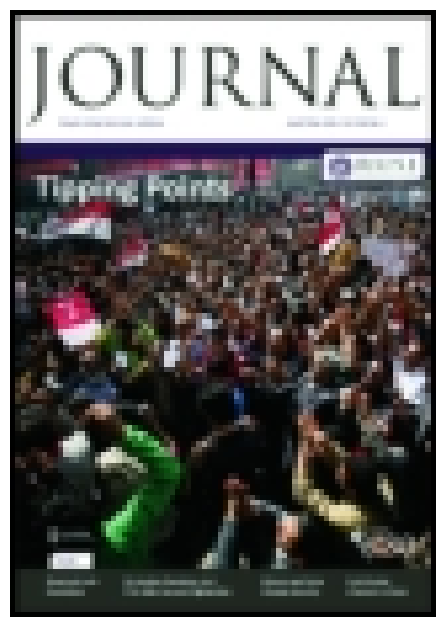

Royal United Services Institution. J ournal

Publication details, including instructions for authors and subscription information: http:// www. tandfonline.com/ loi/rusi 19

\title{
Army Medical Organization in War, with Suggestions as to Militia and Volunteer
}

Surgeon-Major G. J.H. Evatt M.D., A.M.D.

Published online: 11 Sep 2009.

To cite this article: Surgeon-Major G. J.H. Evatt M.D., A.M.D. (1884) Army Medical Organization in War, with Suggestions as to Militia and Volunteer, Royal United Services Institution. J ournal, 28:123, 1-30, DOI: 10.1080/03071848409430446

To link to this article: http://

dx. doi. org/ 10.1080/03071848409430446

Taylor \& Francis makes every effort to ensure the accuracy of all the information (the "Content") contained in the 
publications on our platform. However, Taylor \& Francis, our agents, and our licensors make no representations or warranties whatsoever as to the accuracy, completeness, or suitability for any purpose of the Content. Any opinions and views expressed in this publication are the opinions and views of the authors, and are not the views of or endorsed by Taylor \& Francis. The accuracy of the Content should not be relied upon and should be independently verified with primary sources of information. Taylor and Francis shall not be liable for any losses, actions, claims, proceedings, demands, costs, expenses, damages, and other liabilities whatsoever or howsoever caused arising directly or indirectly in connection with, in relation to or arising out of the use of the Content.

This article may be used for research, teaching, and private study purposes. Any substantial or systematic reproduction, redistribution, reselling, loan, sub-licensing, systematic supply, or distribution in any form to anyone is expressly forbidden. Terms \& Conditions of access and use can be found at http://www.tandfonline.com/page/terms-andconditions 


\section{gounal almited Sertute alnstitu}

\begin{tabular}{|lll}
\hline Vor. XXVIII. & 1884. & No. C2 \\
\hline
\end{tabular}

Friday, Januarg $18,1884$.

Professor LONGMORE, C.B., Army Medical School, N in the Chair.

\section{ARMY MEDICAL ORGANIZATION IN WAR, WIT GESTIONS AS TO MILITIA AND VOLUNTEER}

$$
\text { By Surgeon-Major G. J. H. ErATt, M.D., A.M.D. }
$$

The Crairyax : Iadies and gentlemen, before introducing Surgeon-N who is to gire us a lecture this afternoon on some of the arrangemen plying the needs of the sick and wounded in time of war, permit me word on the circumstance of my being in the honourable position of your I should hare much preferred secing some General Oflicer of lart crperience, or somo one wbose official position has led him to discliarg military administration on a larger scale, occupring the chair on this $o$ it eems to me that the fact of a medical Officer being placed in the Chairman may mske it appear that army hospital organization and adr in the field are regarded as simply a surgeon's matter; whereas, when w the large acsle on which field hospital establishments are organized in 1 das, their costliness, the intimate way in which their working is bound $v$ work of many other army departments, and when we remember the in good or ill on a whole force, which ties cxert according as they are organized and conducted, it becomes evident that the subject is by no $\mathrm{me}$ a surgical one, but one that deeply concerns all ranks of the Army from to the lowest. Howerer, I hare been asked to take the chair in a manne I did not feel I could decline to accept the post, and, trusting to your in am here to diecharge its duties. Allow me now to introducc Surgcon-M our lecturer, to you. He is a medical Officer of etanding in the Scrricc. in the Perak expedition of 1876 , and subsequently during the war in $A$ and has long been known both in his own branch of the Scrrice, a: branches, as haring deroted a good deal of time and attention to the military hospital organization. He has also made the subject familis outside the limits of military lifo by his writings. He will doubtless b us many remarks and suggestions that hare been carefully considered and that will be worthy the consideration of us his auditors.

FOL. XXVIII. 
Dr. Evatr : I propose in this paper discussing the subject of our medical organization in war, and to make certain suggestions as to jts more efficient working, and farther to lay down certain proposals as to the aid we should receive from the Militia and Volunteer services of this country in order to secure war success.

I trast you will allow mo at the beginning of my paper to say how important a fanction this Institution fulfils, inasmuch as it allows an Officer of any branch of the Serrico to come here and offer his sugges. tions is to weak points which, in his opinion, may exist in the Serrice; and how important, in my hamble opinion, it is to cncourage and not to stifle such expression of opinion, provided always the just demands of a fair discipline are satisfied.

The medical service is in this respect of free expression of opinion more bandicapped certainly than the artillery or engineer corps, for these latter arms of the Servico have their own corps journals, where an Officer of any rank, senior or junior, may open up, under his own name, the most vital or radical discussions as to his corps organization. We as jet have no such jourual, and hence the Officer who feels any changes desirable is forced to have recourse to other means of a rabening public opinion far less weighty than signed papers.

In the first place I haro to complain that-so far as my personal experience goes in the Serrice-the subject of military medical organization for war has received little study by -military Oflicers, and I can count on my fingers the number of Officers I have met who fully appreciated tho fact that thes-that is, the purely executivo Officers of the Army - are to-day as absolutely responsible for medical war efficiency as for the efficiency of the artillery or any other branch of army service. Few great military leaders liave disowned this responsibility; on the contrary, the more one stadies the lives of the greal, soldiers of past centuries, the more one can see that, according to their lights and to the then prevailing views of preserving life from disease, those military leaders were quite ahead of the age they lived in, and they felt for their men an abundant sympathy in gaard. ing them against breakdown from sickness, and, if sick, did as mach as they could to make them comfortable. I complain that to-day, in our Arms, I fuil to find any general knowledge of medical war wants diffused through the Serrice; and that while the medical sorrice is strnggling to put itself into unison with modern war demands, it finds itself haudicnpped, and not supported by current military opinion.

That it should be so is very lamentable; but I blame the medical service for much of this apathy or ignorance, for we hare not taught the Army as we should hare done. Had we bat explained to Officer and soldier by lectures and demonstrations what our wants and uims were, we should have killed out opposition, and made partizans; instead of opponents, of the military Officer. Influenced by such views as these, I ask to-day to be permitted to explain what the aims of the more recent medical changes in the Army were, and why wo have broken with the past organization of the medical service.

To understand the present system, I must ask you to go back with mo thirty fears to 1853 , and the year that succeeded it, and see what 
example, and see how we were then situated as regards Bystem of the medical service.

The medical service then consisted of a grouping of medica commissioned by fours, threes, or singly, to erery battalion o These Officers wore the regimental uniform, were under the of the battalion commander, and alministered their regiment talion hospitals under the control and on the responsibilit military commander of each unit.

In every garison there were a series of small battalion, re or battery hospitals, cach entirely distinet and separate, v sick of cach battery or battalion was treated by its own or battery doctor,

The nursing was done by a regimental hospital sergeas certain number of privates of each battalion who were $f$ the Commanding Officer for duty in the wards.

The hospital sergeant was the executive agent of the mili1 mander to maintain disciplino in the hospital, and to see medical Oficer's ordens were carried ont, for the army surgeo had no definite power of command orer cither sergeant, ore patients, but referred all questions of the kind to the milit mander. If a regimental surgeon went sick or went on lea doctor, of which there were rome sixty or seventy in the Se) employed in filling up the sick man's place; but still the sar went on, and the staff doctor was simply the locum tene; absent man.

For every detail of work in the regimental hospitnl the $O A$ manding the reginaent was officially responsible, save only a medical treatment. The discipline was done by the Colon; were issucd by the Adjutant; the Qunrtermaster did the and stores work, and the orderlies of the battalion did the $n$

There were not in Engtand in 1854 more than three, if : general hospitals; all the sick wero subdivided in each garı small groups of regímental hospitals. An Army Corps consis all know, of about forty-seven units, divided into divisions, and corps troops. When the army went to the Eastern c the Army Corps had with each of the forty-seven units ar varying in size according to the size of the unit. Whateve hospitals were, they were purely regimental; the doctors regimental uniform, and no authority existed for moving tl their battalions, or, if they were moved, no power existed to sergeants and nursing orderlies-meu quito as important way as the doctors themselves.

This is what is everywhere called the regimental syster 185t it was put to the test by actual war. An army exists if it fulfils that function, it is good, if it fails in that duty, $t$ l ever successful as a social organization, however plensant as of comradeship, however fall of interest and romance it ma a shan, and had better bo cleared away. I maintain that 
failure; why, we shall now proceed to discorer.

Whaterer the old-fashioned campaigns of last centr their easy marches, their slow manceurring, their retir or eight months of each sear into winter cantonments, a ditferent thing. To-day rapidity in movement is a dis military success. Tho army that unencumbered can $r$ blow at the enemy, is the army that has many points $i$ the game of vistory. I say now that any army whic: modern war to carrs forward with it its sick and we principle implied by the regimental hospital, is doon The heariest burden, the most killing weight an arm with it, is the sick and wounded man, and how to get really the keynote of all modern medical organization in

Let us, returning to the Eastern Army of 1854, see then medical organization it fulfiled the denands of Take its ambulance system on the ficld; go to the 1 Alma on the erening of 20th September, 1854, and see there. The total of regimental army ductors and orderlies with the Army Corps that tock part in the 1 was ample and sufficient under better organization to $b$. by the comparatively few wounded.

There was not any attempt at ambulance organization. sargeons of the regiments under fire, aided by the banc away, or tried to carry awny, the battalion wounded. no trained regimental bearers, no bearer-companies, no 1 no ambalances, no hospital corps, no equipped hospi behind all was. the chaos of Scatiri" with its "dreary pain." :

I will ask you to put yourself in the place of tho batt of September, 1854, as he stood that night on the hillsid and saw his friends and comrades lying on the grounc help them, no ambulances to carry them, no hospital , them, the bare 'tween decks of the empty transport to be ships, and trusting to the sailors of the fleet for the h: ased as stretchers to carry them to their ships. I wi think of Thompson of the 4.4th Regiment left on th with 400 wounded Russians with no attendant sare his s and say was it possible for ns to stand by so fatal a systc

The faults I find with the system of 1854-55 are In the first place, by keeping the sick of the army in a of small regimental hospitals in a garrison jou effectaal real professional progress amongst the doctors. It is alm for the small experience of a battery or singlo regimen peace to give a large field for medical study, and. isolation of the doctors that intellectual friction whic produces progress, is not developed. Secondly, as reg if you make sour nursing orderlies merely chance men t: regiment, you cannot derelop a body of trained nurses $v$ 
was the one of hospital sergcant, and no intelligent private como if he is to remain always a private. In dereloping then the old system failed to provide the best.

As regards hospital administration again it failed, becanse a great hospital work, you must bo trained in great hospitals. jou cannot practise brigado movements with a corporal's \& jou cannot make a doctor, traincd in a small hospital with one sergeant and a few orderlies and some twenty or thirty patii suddenly to the power of administratiug and controlling $g$ hospitals with hundreds of sick. $\mathrm{H}_{0}$ is paralyzed and over by the responsibility, and as by having battalion hospitals you your need of a hospital corps, when war comes you are left subordinates, and hare to fall back on the scratch tcams of pensioners of 1854-55. But if you do this your patients your hospitals break down and becomo tho byeword of the ce Again, if you attach your medical men by threes and battalions and render them immobile, then when you go or paign or into a fight, if one corps is burdened with sick or and another corps is fit and well, you overwork your doctor sickly corps, whilo the doctors of tho unengaged and healt ments remain idle.

So it was at the Alma, the whole of the doctors of the $b$ of the divisions not under fire were quite idle, but an overw labour rested on the doctors of the engaged battalions.

forced nolens colens to fall back on a larger unit than tho I and you come as all arnies come in the end, to the divisio But if yon aro to kecp your soldiers in good morale, you mast see that if wounded in the fight aid is ready to hand. I do it aid to take the bandsmen and make them dressers of $v$ The band itself as music is an aid, and an important aid, to in das of battle, and to break it up is to liandicap jourself against You must have trained bearers able to check bleeding and real aid to the saffering; bandsmen never.could do this. $\mathrm{Bn}$ these regimental bearers, you need to lare, for the sume reaso: the doctors, some larger nnit than the regimental ambulam, that is essential and raluable, but it is insufficient. Tho 1 doctor cannot carry chloroform in anj quantity, nor cooking. the all-important soup, nor brandy ouough for many woun operating tables and instraments demanded by modern surge you need some belp between tho battalion surgeon and 1 hospital farther in the rear, and that holp is the admirabli company, of which I shall speak directly.

But if we go a step further, wo come to the climax of the and that is, that you cannot in war have a regimental hos seriously sick or wounded men. In the first place, if a di told off for an attack, one brigade is sure to suffer more $t$ other, for one is in support and oue is in reserre. 'I'his mea wounded in one brigade than tho other, and you need some ] 
again to the field hospital common to the whole division.

But say that we have regimental hospitals, and that regimental hospitals of a division have all a fair propo and rounded, and the division is to march forward, whal the sick? If you take them with you, you will cortainly the enemy, for you will be creeping along, encumbere trains of sick and rounded, and that certainly is not $w$ jou leave the regimental hospitals behind, jou advance medical aid.

And think too of the doctor and the scratch hospital You have during peace deprived him of all poxer of co his subordinates, the Colonel had the discipline, the Adj the orders, the Quartermaster did the traneport and ti and, lo! all are now marched on, and the unfortunato has been tanght never to take any initiative, is now become Commander, Adjutant, Quartermaster, and Tran all in one. It is not possible; so slowly we work bacl Beries of divisional hospitals, with their own nurses, their ( masters, their own Transport, and controlled by doctor peace to direct and manage their own hospitals in war.

Let us again turn and see what was the end of this $\mathbf{C r}$ for you must remember that although the Crimea and i great troubles, tho Crimean campaign was not really a wa War means morement, and the Crimean Army never mo caliy it marched to the heights above Sebastopol, and itself in, it hutted itself, and there it remained until $t$ ] Such wars are raro. It was really a great caso of sitting fighting, and any ono can see that if transport troubles troubles beset the sitting army that lay in front of Sebast more heavily the same troubles would hare fallen upon th long line of advance into the Russian interior had taken line of communication had required to be beld.

But public opinion demanded a full inquirs into 1 medical experiences, and in 1857 and 1858 Sjdney Herbe sion sat and iutrodaced a number of iuprorcments, bnt no radical change, and it really made war-efficiency little the range of practical achicrement that it was before 1851-55. It gare the doctors rank and pay. It founded a hospital corps; it dereloped a kind of hospital com formed two general hospitals, sapposed to be training sc] work; bat it still stood by the fatal error of the maintain mental hospital and the regimental doctors in peace, an killed out all the other adrantages.

As I have said previously, if yon keep up regimen you paralyze our training for war, and if you take all of the doctor's hands in peace, and make some one else you derelop a body of reak-kneed men, who, when war paralyzed by its demands on their energy. 
they are vis und was sumuna. recognized our sanitary duties in preventing disease than fo advance in war organization. The Corps of orderlies he for not linked to us in title or control or sympathy. Of the $t$ " hospitals he founded the one which bears his name was $n$ thing but a series of regimental hospitals thrown confusedly and Netley is a great school, with a permanent staff who do war. The purveyors, who were intended to be our assistant agents, became in the end quite independent of us, and the : relief to soldiers on the field was so badly dealt with that, at mittee on Army Transport in 1866, a very pretty discus between the then Director-General of the Medical Service, Purveyor, and the Chief of the Transport Service as to who responsible for removing the wounded off the field. Nol who was responsible even in 1866.

Bat the great means of securing progress in our medic were the War of the Rebellion in America, the campaign $c$ and the disasters of Sedan and its sequences. We bega foreign systems more and more, and in $18 \% 3$ and subsequen have developed and are developing a new sysfem, which I stand scrutiny alike by the scientific soldier, the humanitari: physician.

The scheme of unification now slowly making progress in was introduced in March, 1873, further developed in 1876, a it receired a still further derelopment. It is still, howc infancy, and when you remember what time it takes in I -introduce any change, I think we have not done badly.

In 1873 the medical Officers were remored from $t$ regiments in which they were commissioned, and the regimental doctors were unified into the Army Medical Def

Regimental hospitals as distinct units in each gar abolished and replaced by central garrison hospitals. Hospital Corps was developed from its previous scatterec into a strong corps doing all hospital duties, and the medit were made responsible for the management and control of the in peace and war.

Gradnally a body of fifty-two Quartermasters wero deve were to have charge of the subsidiary duties of storel paymaster of the hospitals, and in 1877 the command of tl Corps was given over to the doctors. tion.

But what interests us most is the war scheme of the 187.

Firstly, the three or four doctors of each battalion were one medical Officer who is posted to the unit, be it battery or regiment, at the outbreak of the campaign, and who re it throughout the war. If he gets sick or wounded he is once from the divisional doctors. In war, sickness is rife, frequent, battalions are up to war strength, and there is $f$ : 
to fill them up in war. A medical man posted to so sr would probably come to grief from need of work.

In war time, however, besides the battalion surgeon $t$ body of regimental stretcher bearers, sixteen men trained work who assist the surgeon in giviug first aid on the fiel keeps to its music, and a distinct body of men is tol wounded. This surgeon has also with him medicino box portable medicines and first dressings, but there is no battery hospital.

If a man be sick or wounded he is sent to one of the $f$ of the division.

If you look at the Diagram on the wall you see at a glane medical system for an army corps in the field. There ar units in the army corps, and there are forty-seren surgeo: uuits. There are in addition forty-seven detachments $c$ bearers.

But an entirely new organization now intervenes, that: company. Of these there are four with an army corps, I each of the three divisions, and the fourth is divid companies, one half with the cavalry brigade, and one 1 corps troops. I claim for tho bearer company that it is and most useful outcome of modern humanity in dea wounded in war. No one can see it at work at Alder recognizing at once its eminently practical character, enormous boon it is to the soldier in war. It seems to mu that it should be working at Aldershot in remoto parts by itself, and not taking part in every field day, and not alone, but at every great military centre where sol nustered. Its work is most realistic, most thorongh absolutely certain it only needs to be seen to be appreciat

In war time this company consists of eight medical some 200 Army Hospital Corps and Transport men w' them surgery wagons containing an elaborate supply of operating tables and dressing supplies, cooking-pots for various stimulants and suitable refreshment for the $v$ ambulance wagons thirty-three in number for the remova: This bearer-company can break into two half bearer-com is believed that Lord Morley's Committee will se definitely into distinct companies. It is merely a quest What is the function of these companies? When a mal the 1st Battalion, 1st Brigade, 1st Division, the battalion him to the regimental surgeon who stops bleeding and a] first application to the wound, giving water or brandy if $\mathrm{p}$ wounded man is then carricd to the rear until he meets $t$ wagons of the bearer-company and the Army Hospital C $\mathrm{He}$ is then taken over from the regimental men and con dressing station of the bearer-company. This is $t$ 

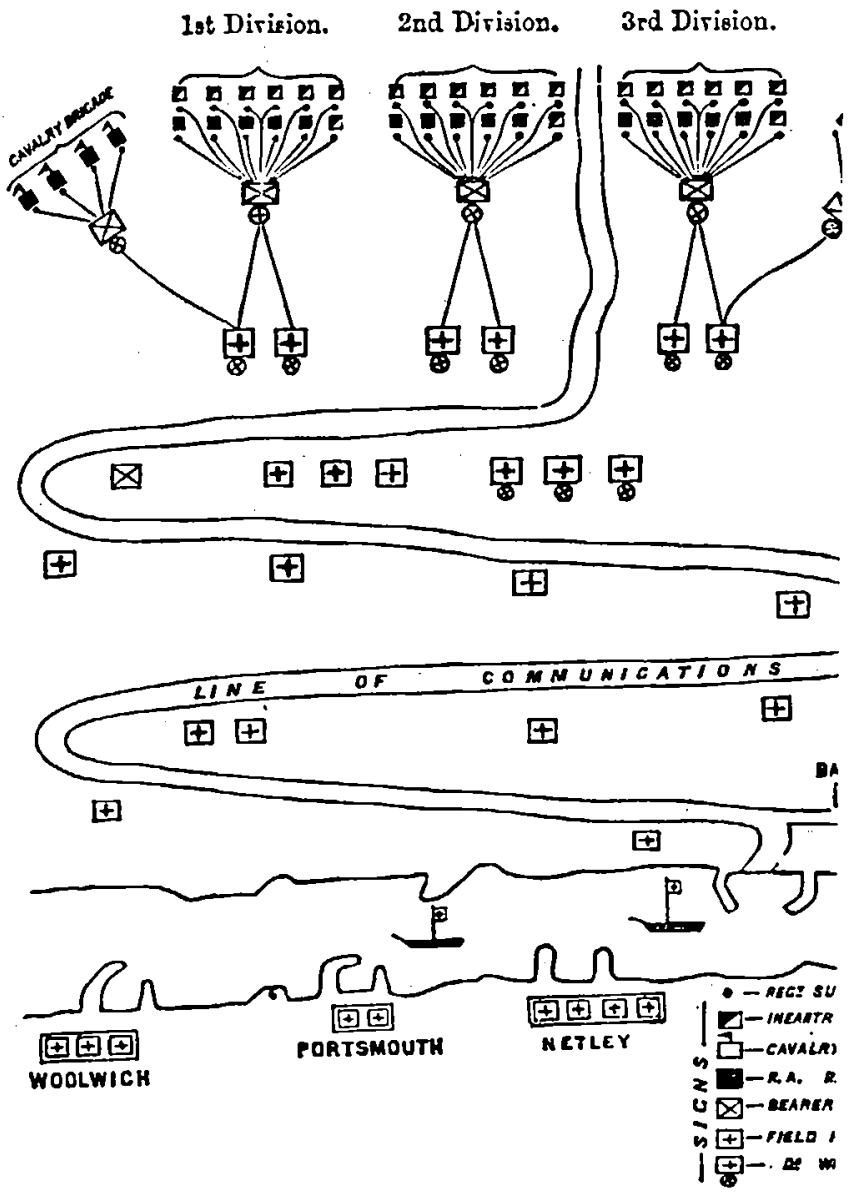

wine, di., and finally passed back by the ambolance Ta: field hospitals, which must bo always farther in the rear, a which might cause great delar.

The bearer-company dressing station is really a very lig hospital, and a great collecting place of the divisional wC may sometimes remain there until the field hospital is al its way through the crowded roads behind the fight and over the wounded. All this collection and removal of $w$ 
other technical drill. The great pity secms to me to $b$ done with the Army at every ficld day, so that the see and learu what they now do not know, that is, what pany is, how it works, and whit is its organization.

I hope that one day Generals will arise who will st pans and sco if it bo not really what I claim it to be, organization and most essential to the Service. A few s at the Alma might hare shortened tho war very $m$ : sared many valuablo lives.

In Egypt, as jou know, Lord WVolscley stated that t the rounded was well done, and if it kere known with difficulty tho companies got their needful transport, rould say that the doctors had done well there.

When the bearer-company has handed over tho wC field hospitals, it arain adrances with the advancing arm its place with its division.

It is still a young crcation, slowly developing itself, b? absolutely assured. In onr futare wars it will bo the and valued unit in the Army.

We now come to the field hospital. We saw that in an army corps we had forty-seven regimental hospitals, fr without trained nurses, withont their own Quartermast pletely organized to break down when left behind by 1 regiment.

These forty-seren fair-weather yachts that perished ir war have been replaced by twenty-five field hospitals, c in themselves. Every army corps of 36,000 men har these twenty-five field hospitals, each supposed to be $r$. feed, and treat 200 wounded or sick men. Their equipn in special wagons, they have abundant drags, instrumt cooking and feeding requisites, and are as mobile as artillery. There are seven doctors to each hospital, one 1 of the Army Hospital Curps, but alas! ouly thirty-s corps subordinates. Of this more by-and-bye.

These twenty-five hospitals are posted, ins jou ca diagram, two to each division, making six, six more in 1 the front of the army, and thirteen alung the lines of $\mathrm{c}$ and at the base. When an action is fought, the mounc first to the dressing station and thence to the field ho division, these being filled, halt apon tho battle ground, hospitals out of the reserve are posted to the division, $p$ able to advance with its bearer-companies and ficld hi for another fight. The sick and wounded in the lalted 1 if they recover, rejoin their battalions, if they get serionsly hurt they pass back along the lines of commu hospital to hospital to the baso hospitals. Here they I they recover, rejoin their battalions, or if still ill, retur in those rell found floating hotels called hospital ships wl 


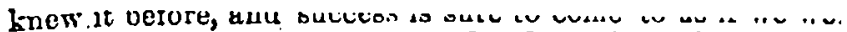
lines, which are themselves mercls ndaptations of tho Gern We can tell exactly how a soldier ought to be cared for, and $t$ possible in the confused old days. I do not claim for $I$ perfection in detail, for it has .unfortunately many $d$ its principle is, I think, ebsolutely true, and no soldier ca with it on that ground. Tho fact is that tho medical striving to force upon the Army a system of war organizat to assist the fighting soldier in achieving war success, and a rerage soldier does not. see it. It only. nceds. education its great advantages orer past. systems. As it gives a m field for medical energy and power of work, so it demands from tho medical Officers to work it, but it is entirely tho the Army that the medical Officers should have freo scope work. Thero is ample work for both classes of Office: purely military line much has to be done by the purc teach his men the very great and urgent deniands of modi knowledgre. Leave to us tho hospitals and we will lea. them perfect, and it will in the end be for the best.

One of Lord Morley's Commission wished to have the de posted to battalions in order that they might learn to obe to command. This is in truth quite what the old system n any army doctor. Having two masters, viz., the princi Officer and the regimental commander, we played of ono other, and certainly did not obey very much.

As to command, when did a battalion surgeon over le: mand? Why crers rule and regulation was framed to sach.acts. An old regimental surgeon never gare an $c$ man, and as the $\Lambda$ rmy rules reared him, so he grow up, and first deprived bim of all power, ho was expected in war to wonders on his own account.

It is not in such ways that mon are trained for accepti bility. We are now on a better path, and sball no doubt $n$ progress.

I will now ask you to agree with me that field hospitals and should be efficient for the work they are called on to $\dot{c}$

I regret to say that manned as they are to-day it $i$ impossible for them to do good work; nay, indeed, to But the remedy is easy, and very simple.

To nurse 200 si:k men in a war hospital is a heary tas] 80 in a peace hospital, for in peace many patients are triv many are convalescent.

In war few of either are to be found in field hospitt cases do not come to war hospitals, and convalesceuts are a depôt near the base. At any rate, the general aver patients are far more severe than peace patients. Now get one orderly to ten patients. and in war one to nine. pletels insufficient. Nasal hospitals get one per $7 \frac{1}{2} \mathrm{~F}$ 
table yon will find that it gives only twenty-two for the I

Establishment of an English Field Ilospital for 200

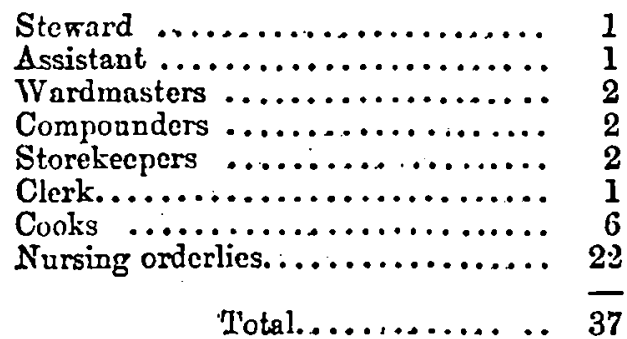

This allowance of thirty-seven men is completely insal good work. If you want nursing well done you must. I fair reliefs. Twenty-two men cannot nurse 200 with a thorough work. Increase it to forty per 200, or ono F and the machine will work. If you read the Report of $L$ Comnittec you will see in every page eridence of compl of the nursing orderlies; so if in the next campaign wo a work we must have men given.us to do it. Take, again six are allowed for 200 men, and that cooking for the trying, for there are many dishes to bo made separately, ar has to be cut up in small portions. We need eight cook fifty sick.

Again, as to clerk8, if wo nre to keep regiments inforn their mon are, we need a clerk to do it, and we hare only keep all the records and carry on the large correspondenc at least four clerks for the 200-bed hospital, so that if 1 detached there may be two clerks for it. But the gra overwork and threatencd breakdown is tho complete ab. coarser assistance needed in a war hospital.

I have placed hero a comparative table (see p. 13) of at an English war hospital for 200 beds, and you will see t] at once.

In an Finglish feld hospital there is not one man allop water for the hospital. This is the most killing want, as $\mathrm{i}$ root of all cleanliness, and if $I$ am to get water to my hos have men to do it. You do not ask a battery commander guns with half the proper number necessary for the work we to work a ficld lospital on such conditions?

We want this question to bo denlt with before onr nex for we shall certainly go to grief if we do not get mer work. Wo are asked to do impossibilitics, and we only as questions be looked into to see that no man, however er work under such a handicap. 


\begin{tabular}{|c|c|c|}
\hline Clnss of Serrant. & English Scale. & Indian. \\
\hline 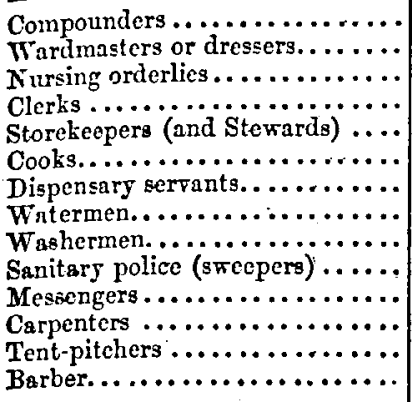 & $\begin{array}{r}2 \\
2 \\
22 \\
1 \\
4 \\
6 \\
0 \\
0 \\
0 \\
0 \\
0 \\
0 \\
0 \\
0 \\
\end{array}$ & $\begin{array}{r}4 \\
8 \\
29 \\
1 \\
7 \\
9 \\
8 \\
15 \\
5 \\
23 \\
1 \\
1 \\
10 \\
1\end{array}$ \\
\hline $\begin{array}{l}\text { Total for } 1 \text { hospital............ } \\
\text { Total for the } 25 \text { hospitals of an } \\
\text { Army Corps } \ldots \ldots \ldots \ldots \ldots \ldots \ldots\end{array}$ & $\begin{array}{r}37 \\
925\end{array}$ & $\begin{array}{r}122 \\
3,050\end{array}$ \\
\hline
\end{tabular}

We want at least cight fatigue men to supply water for $t l$ This will give two men for each fifty sick. When we c number of baths, the washing in and about a hospital, it once that many men are needed.

Again, as to conservancy or sanitary police. In peac admirable drains to carry away all sewage from our hosp war we have nothing of the kind, and in a hospital camp ir men are much needed. In fact, it is deadly to the hospital them. I say, again, you are asking us to do impossibilities asking us to make bricks not only without straw, but wi and we cannot do it. You are asking us to toil as we do slaves at the coarsest menial work, and yet you give us no as pioneers and to keep the place healthy and clean. The comes in great moments of trial there is no work I will the sick man, but it is quite another affair to embark from $t$. of a campaign and to know that no proper provision is this all-important work. Again, as to washing, we $h$ single man giren us to. wash the clothes, and jet we are bla clothes are not clean.

We have, then, to appeal against this want of forethou hurries us to war without the necessary means of doing and while'we are continually urged to be professional, given us to carry water, to act as sanitary cleansers, 0 patients' clothes. Again, as to messengers, if I want to sen a regiment or to an Officer close by my camp, I have no messenger, and as a consequence I must take a nursing orde1 overworked to do messenger duty, and so neglect of the sic 
ninery-xilree men are not only nor too mucu, wut varidy make a lospital work. You can now see how legitim complaints, and how heartbreaking it is to go into the unit completely organized for failnre.

If England, or the Army, demands that her soldiers be war, it will not do for her to develop a flash of warmhearte a campaign occars, and accuse her doctors of want of sy neglect. England has her duty to perform, and that is peace to the fair and just demands of her dostors; and as be legitimate, to grant them. Thus, and thus only, can w come. Nor do we in any way absolve the military, corr their responsibility. Command has its duties as well as it: one of its duties, as high as any, is to.see that, before campaign, the just demands of the medical service are met not in all these matters legislate on the bass of herois! sacrifice. The sentry at the outposts keeps rigilant nol sacrifice, but because he is regularly relieved, and so with You must not draw op codes for saints and angels, but men, who get tired if overworked, get lungry if not prope who feel bitter in their heart if treated unfairly. These which aro not fully dealt with in Lord Dlorley's. Cowmitt, aro as tiue as anjthing can be, and no Otficer I have spok subject can deny their truth, We need, then, largo reser and I will, in a few minutes, when concluding this paper they can be obtained.

Again, tako another point. Whero are our field hosI present moment? 'They aro entombed in Woolwich Arsent the Egyptian campaign no one ever saw one taken out of Officers who saw them in use in Erypt saw them then $f$ time, and no wonder that difficnlty occurred as to the $c$ their equipment. In my opinion they should be taken store-room, and posted to each divisional centre, and ther and ourselves would see whit they aro like, and find faul if necessary.in peace, so that when war comes they may This is the way the artillery is efficient. The battery comr not read about his battery only, or hear that it is in a st Woolwich Arsenal. He has his guns with him, and J accustomed to them, and ho and his men know how to Give us and our meri an equal chance. Let us have a $\mathrm{n}$ Jear and practise our field work with the Army.

But, again, take another point. We hare a Chicf Medic Deputy-Surgeon-General, who is responsible for the medic ments of the twelre regiments in the division, for the bear and for at least two field hospilals. Every soldier bnor immense amount of correspondence this involyes and what position the post is. Yet while the artillery commander an Engineer of tho.division have both Officer assistants as Ad divisional chief has no one whaterer to assist him, and be 
the nela whuts nuuse wh the remedy for this is not dific results on war efficiency. The rem giro the divisional principal medical Officer a junior medical his secretary or Adjutant or personal assistant.

The attention of the Army should also be drawn to anc urgent detail of our war system, I mean the relations wh: exist between the Army commander in the field, and the chi Offecr sorring with him. I maintain that it is entirely in $t$ of the Service and of the nation that rules of the cle: should bo laid down by the Secretary of War, defining thi of both these officials. All will agree, $I$ think, that in confidential relations should exist between them.

A new theory, howerer, is now being advanced that the Gcneral with an Army in the field is not to be conside General's Staff Officer, but simply as the hend of a subsidia ment, on a par with the smallest and least, important bras Service. This is not the history of successfal campaigns. I a highly injurious idea that would deny to the Chief Surg Army the status of a confidential Staff Officer of the mander. If you so cut off our chief from personal and coutact with tho General, it will react on the wholo of $t$ Bervice in the field, and we shall feel that he is not in the of the Army commander, and that there is no one to be spr. our needs, and of the wants of the sick at headquarter: condition of affairs will paralyze onr energies, and injure o corps.

To-day, wo need above all things definiteness as to or Either we should bo accepted wholly:by the Army, or wo set wholly free from it, and allowed to work altogether own responsible ehiefs as a distinct and separate departm State. Wo can suceeed perfectly under either condition cannot exist at all if wo bo indefinitcly dealt with, if be in the Army, but not of $i t ;$ to be blamed for failure left unconsidered in peace; to bo thrown orer for want jet not listened to in our cry for assistanco; to bo hele the honds of military discipline, set denied military , privileges; to bo required to sharo in all the risks and of field service, jet denied the share of the glory of vic despite pay however remunerative, and rask however hig fail England in the hour of her need.

We read military histors, and we gange rery thoroughl in the military machine. We recognize the bravery of and the derotion of the Officer, and we estimato perfectly th for war work of the battalion and the battery. But we alsc why and where jour armies have failed. They have fail are called the Departments, that is to say in tho Commiss Transport, and in the Medical services, and it is for the 1 if it sluall alwars bo so. 
Ho ane, sees unat in the Serrice, and make every man in the Army fro lowest, feel that all are working for the same endsuccess of the nation, and that the victory achieved $b$ his victory, and its failure is his disgrace.

These seem to me to be the only lines on which to.da England can be successfully worked, and there is no re: why they should not be made the rule.

If they cannot be made the gaiding principle for the rate set the medical service free from the military a and we will organize as the "Red Cross" societies orgar up under the Gorernment a Medical Department for civi duties alike, and will: send into the field a contingent c organized under its own chiefs, to . be completely respo own failure, and completely rewarded for its own succes

There is another very important question for us in we the commissariat question. Certain reformers of $\mathrm{L}$ school maintain that we should have our own commi shape of a distinct Purreyor's Department. We are, free the general Army commissariat from all respo feeding the sick, and we, a weak, poorly-manned depar derelop a rival commissariat for ourselves and let the gr sariat go free. Now apply this principle to the Egyptian c: us remember that 583 per 1,000-that is nearly six mer ten in the Army-went sick during that brief campaign. of our weak establishments, to feed, and that, too, dail out of every ten in the Army? But when we remen Army commissariat did not succeed in feeding the successfully, with all its large establishments and mass subordinates, it is hardly to be expected that we wonld our infinitesimally smaller commissariat section. .In $n$ should do nothing of the kind. We should hold on $t$ principle that the General of the Army is responsible fo of his men, sick or well. That if he goes to war, he of all think out how his men are to be provided with $f$ the sick soldier has a distinct elaim on the general $A$ sariat; and just as you post junior commissariat Officer missariat charge of brigades and divisions, so you sh war is imminent, post commissariat Officers to the base to the varions units : of the medical serrice, and it $s$ business to provide such food and supplies as the medi for their sick. If this cannot be done, and we are to separate commissariat department to ration our own 583: of the Army, we might as well simply undertake to ra odd men remaining out of hospital! An army with a $p$ commissariat service is really no army at all. It is certa engine, and no General has a claim to such, a title n 
giren to us. We should have a small section of purely mec transport; that is to say, enough to movo our lospital w: cnough to horse the ambulances of the benrer-compani transport should be wholly our own, but be available for all ce when not specially needed for hospital serrice.

In our Army the question of transport has always been o siderable concern, because, as it seems to me, it has been litt in peace. With numbers of civilians trained and accustome to look after horses, we have, as jet, no militia transport c I feel confident that one could embody, either from the mili or by direct enlistment from the peasantry, several thousanc militia men accustomed dails to the care and driving of hor: not adopt such a course and apply to the great supply se principles already existing in tho other branches of the service?

We have a reserve of Officers, why not call upon ther themselves for commissariat and transport duties as well duties of the front line of the Army? As to the horses reserve of horses is as easily formed as an army reserve only somebody takes up the question and sees it through.

As to our medical transport, we need only be -toli we are to look for it to the Army or not. If the Arm? and if we are allowed to appeal to England for mon and can get the best of both to come and help us.

But I think a militii transport serrice, and indeed als commissariat corps of civil butchers and bakers, is as eas as a militia artillery regiment. If, as is often said, the Arr part of the nation, the more we weld together the Arm people, the better for our war success.

Every hospital embarking for war shonld march down to with its wagons, its horses, its drivers, its equipment, and i staff as complete as a battery of artillery is complete, and so in the enemy's country. This was the aim of the medic party, and this aim will surely be realized as time goes on.

Again, at the base of operations we need some body of will do the unlording of the hospital ships and medical 1 and who will move the sick from the great base hospitals tc and the railways. For this rork we haro no one now det jou mas read in Lord Morley's Report that, while the fe orderlies were engared nursing all day in the hospital, waiting all night at the station, to convoy and carry by har to the hospital. If anybody imagines that you can thus men and jet make the hospital work with accuracy, they a mistaken. I would suggest, then, half a bearer-company at the base of operations for this special duty. You should for your lines of communication two or more bearer-com use as sick convoys, either to man the ambulance trains con 
There is one word more I would say before props Volunteer schemes.

It seems to me a sad thing that, as a department, we teach the Officers of the Army and the men what sanil In the long tedium of foreign service and in the wi England, I would have the army doctor teach, by lectr irstruction, sanitary laws, the way to aroid the cc of campaigns. It is lamentable to think how comI Officers and men are of the very first principles of heal I take it that no man is fit to command men and as not know the laws of sauitary science and health pr self.

The ignorance on these subjects in our Army-alwa that needs it most-is very great, and the loss of mer ning of a campaign from want of knowledge how to is a most serions matter in a small army. Man Egsptian sick list ailed simply from parely previ Want of food, want of shelter, and want of knowledg exposure means, contributed largely to it; for, the medical service is not to blame, save that it 1 long era of peace tanght the Army the knowledge it If our cavalry horses had broken down in any numbe: not have been a great outery? We have classes for vet tion at Aldershot and Wool wich. But no combatant C I know, has ever been regularly taught to look after tl men. I notice that the German Officer is taught $t$ sanitary science, yet he, living in his own climate and European wars, does not need it at all so much as ov serves in every possible climate, and is liable to and malarial disease.

But while I thns proposo to teach the combatant $O$ forget to say that you must let us learn all we can ours however, your Army surgeons are shut out from all $c$ London schools. The Army Medical Department $h$ contact with the great centres of London medical and ledge. The London garrison is altogether in the hand: Guards doctors, and they alone have the chance of seei of the London ciril leaders of medical science. Te day a great central military hospital for the whol garrison will be formed either at Chelsea or elsewhel who have to spend long gears on foreign service in I Ceylon, and China, may have the chance of meeting th civil doctors, and learning all we can from them.

I now turn to the question of how we are to ol reserres needed for war. We do not necd heavy peace because in peace our hospitals have all the subsidiar water supply, laundry, messengers, sewage, otherwise 
I think we snouid nave, ul cuurse, vur uwa army reser trained in the hospitals, and passed back into the reserve lik soldiers. But if jou work this reserve too rapidly, we s? hare boys to nurse our sick in peace, and hence wo need extra establishment to be rapidly trained, say for one Jaar, $f$ into the reserve for the remainder of their service. These in addition to the ordinary peace-need of a hospital, and $w$ kind of one year volunteers, as on the German or Frenc We might get many men who would spend a year ir nursing for the sake of getting into civil hospital or nursir ment.

But I think that we ought to have a distinct militia bras Army Hospital Corps, called ont yearly like the ordinary. militia. These men would be equal in number to the needs of army hospitals in war time, so as to free the regular hospital jts reserres for war; 1,500 such men spread over England, Ir Scotland would enable as to be quite certain that when wa wo could call out a body of partially trained attendants replace the regular men. When these men were called out either at Aldershot or at the district centres, it would en: muster sufficient men of the regular and militia hospital cos go through all the field drill of the bearer-company and th and working of feld hospitals, a work of which we are to-day because the hospitals are packed away in Woolwich $\mathrm{Ar}_{\text {i }}$ the regular corps is too weak to go through this field scric do not know a more economical system than this of obtai and I imagine we conld all recruit for it in tho districts. form in it again a militia reserve on the lines of the regul reserve, and so get together a number of mon fit for tho fat of the hospitals in war.

Wo cannot possibly sncceed if the subsidiary services of th are not provided for, and the way to provide for them is 1 far as possible, the methods used by the Army to secure I formation of a militia hospital corps would, at any rate, $g$ men a chance of seeing if they liked the hospital daties; might eventually onlist into the regular service. I think $j$ get the chance of enlisting a militia corps that, scattered as $t$ ] department is over the country, it could secure recruits in $\mathrm{s}$ While we hare artillery, engineer, and infantry militia, I also need a medical militia. The militia educates men for $t$ arm5, and so in like manner would our proposed militia hos] train men for our needs. I beg you will think of this militia scheme. You cannot think to what difficulties we England, even in times of petty wars, by the complete : such a body of men. We have to go about begging for every corps, and in the end the corps is weakened, its $t$ : interfered with, and our nursing work is very indifferent.

Only give us a chance of acting as recruiting sergeants fo 
work in our hospitals. Why should we differ from artill or infantry? Jhey all bave a strong militia help behin who need it greatly, have none. Can anyone devise casier, a more constitutional, or a more common-sense so, let us have it, our want is abore all things men.

We come now to the Volunteer force of the country point ont how completely insufficient its medical servic by modern needs. It has no bearer-companies and no fi in fact, nothing behind the battalion surgeons and $t$ bearers. We need to organize in every count 5 , and $i$ town, a volunteer bearer-company or companies of a volr corps to supplement the already existing volunteer batta I believe that we could enrol in such a corps many hux who feel an interest in ambnlance work, and many sur life would take a commission in such a corps, and drill the bearer-companies and field hospitals. I would orgal panies like ordinary volunteers. Dress them like the 2 Corps, and drill them in all ambulance and field hospita would fill up a great want in the volunteer army, ar also send us many men for a campaign, and we st strengthened for war.

To beyin such a movement you must first of all trai Last year a scheme was put forward asking the me of London to practise ambulance work, and enrol th roluntenr branch of the hospital corps. "Several scho work at this idea, and if the Secrotary of Stato for them a capitation grant, the morement will succeed. inestimable value to England in every way in developi knowledge amongst the civil doctors, and it is therefic that official sanction will be given to the scheme. You sympathy in the movement would be a great aid. I hol day see paraded in. London a battalion of trained med composed of companies made up of students from the politan hospitals who will go through all tho dril corporals, and sergeants, and so train themselves to control the bearer-companies and field hospitals of the $f_{1}$ medical service. Then that day comes we shall ask Guards to meet the students corps in the park, and fo attack of a position; and as they dash forward over the 1 will sonnd the "lie down," and $500 \mathrm{men}$. will throw th the ground as if wounded; the students corps with ambulances, and all the paraphemalia of medical equip sweep over the field, take up the sham wounded, conv dressing station, and go through the routine of sham finally conrey them to regularly pitched field hospital When this day comes we shall provide for London a $m$ sight, and for humanity a real triumph. 
niming to achieve, her heart will be stirred, and we slual] ono desire fulfilled.

Working on these lines, when war has been declared, the General would simply telegraph to the Divisional P.M.O. "“ At once the regular Army Hospital Corps in the district called in to form the nucleus of the field hospital. The dis medical reserre men would join at the same centre to cadre of the nursing staff of the hospital. The militia hos would be called out, and would take over the district hos extra men of the militia reserve joining the district field he the volunteers of the local bearer-company would no dou certain numbers. The whole would then form a complete fie and with their equipment, transport, and staff, would en body for foreign war. This seems easy; and it really is $\mathrm{s}$ needs thinking out in peace, and that all arrangements made beforehand. I firmly believe it will one day come.

I have now ronghly outlined the main points of onr $\mathbf{n c}$ field system. It is an interesting study, and I commenc soldier and to the civil physician for their consideration. have to reckon with new conditions in war, and the growinc of the race will not fail to demand due provision being $m$ sick and wounded. If the establishments demanded are heavy by comparison with the past, you must remembe lemands of a civilized race exceed the demands of old days times; but the remedy against these increased establishn attend to the sanitary condition of the soldier in the fie prevent men going sick. If they do, jou must provide li their care and nursing.

Out of our great troubles in past wars wo in the medi are being ourselres educated as to what wo want, and we in our duty to England and the Army if wo did not boldl needs. The autonomy of the medical corps of the Army is i our success, and the more it is fostered, the moro we sl efficiency in peace and in war. The more we are made de others for success, the more likely we are to fail. If the have made in this paper at all aid to the better understani war needs of the medical serrice, I shall be amply repaid.

The Cnsmmax: The lecturer has now brought before us a rariety for improring the organization of the militars medicul scrrice, especia! war, and it will be adrantageous to us if some gentlemen who hare ha on the various topics which he lias discussed in his paper, many of wl present, will give us the benefit of their abservations, especially with $r$ adrisability and practicability of the additions to the regulation personn supplementary aid that he has proposed for the field hospitals; or, I hand, any alternative views thej may hold which will appear to the better chance of attaining the object that Dr. Eratt has had in view, $\mathrm{E}$ course, we all much desire to see attained, namely, an increase in the our military medieal establishments in time of war.

Mr. K. W. Tsrarox: I am siuply a rolunteer of the last twenty-t ' 
Windsor reriew. I went down there with the rolunteers, acting Major Gastein in the bearer-company. Two field hospitals were : troops. I was told off for No. 1 hospital. We had amongst the $c$ man who came in suffering from heat apoplexy. All the stores perfectly correct, but owing eridently to the cases not being unde the medical Oficers, the material being simply kept in store, whe called for, there was nothing to be found in the cases that $w$ arailable for the purpose. All the material was stuck together. and gutta-percha tissue had been kept in store for such a number was perfectly useless. I think it was from a quarter to half an could find any material suitable for the purpose of applying ice to 'Tliat is my experience of medical stores as ecrred ont to doctors, and necessity of the medical Officers haring the absolute control of stores, and being responsible for the efliciency of the same.

Dr. Lswsox (Inspector-General of IIospitals) : Bcfore offering should hare preferred to hare heard the opinion of the military 1 present upon the subject which Surgeon-JIajor Eratt has brought b are few medical men who do not thoroughly recognize the necessit zation which be reconmends. In fact, as war is carried on nor absolute necessity that we should have the means of suddenly cc medical force upon a giren point with all requisite stores and appl them to do the work. Our present arrangements do not admit of and I merely repeat what I beliere is the general feeling of en Medical Department when I say that it is absolutely necessary tha done before we can derelop the energy which we are willing to under present arrangements we are prerented from doing. Of cou good many points of friction in doing this which will take pla Medical Department and the military departments, and these mu persons acquainted with both sides of the question coming toget arrangements that will obriate them. Certainly the state of de Mredical Department has greatly prerented the efliciency of the : inedical man who wishes to carry out his duties properly is frequ the position in which I mjeelf hare been placed of haring to adop: knew I was not justified in adopting by the Regulations. If anjon knew that I must gire in, but 1 eaw that if $I$ did not do so the Ser been seriously hampered. There is one point which Surgeon-1Iajor to which he does not regard in quite the same light that I.n nequaintance with the Serrice is much more recent than mine. I something rery close upon half a century, and when I entered regimental systeni to which he alludes was prerailing. I had $t$ meeting a great many regimental Oflicers who were thoroughly acqi proceedings in the Peninsular and prerious wars. I quite admit thit prevailing was not such as would enable us to concentrate our forcc point as required so as to meet the necessities of the present daj, bu looks back he will find that that system was deserving of a great d than he seems inclined to gire to it, for I am sure that the amount to the Arung by the Medical Department at that time and under tho: was wortlyy of a great deal of praise. I cerlainly myself strongls I the relations of the Medical Department to the military depart: thoroughly and clearly defined, so that each party may hnow exa depend upon the other in order to carry out the objects desired. II 5ou, Mr. Chairman, are well aware, the Medical Department was carry out a great many improrements, especially with regard to sar but they were deprired of the pover of doing so. Application had the military authorities, and tle result was nothing was done. It $h$ state of things became so bad that the Minister of War sent out a $C$ power to do anything that ther thought right, irrespectire of command or of anjone else, that these improsements were carri 
left it to be supposed that we did not know how to do them.

Brigade-Surgeon Dr. Dox : Allow me to offer a few rords upon on point referred to in Dr. Evatt's rery interesting and, I may say, lueid lecture. We all know his enthusiasm for the subject he has in li: we have had a very good opportunity of judging of his thorough practic of it, I wish particularly to refer to the stress which he laid upon $t$. and duties of bearer-companies in future warfare. As far as 1 can seems to be a great want of appreciation of the important functions company in modern warfare; and of late, particularly in the last $E_{\xi}$ paign, the true duties of the bearer-company wore not, at all cren understood. In these dass, when it no longer takes the wcight of a in lead to kili or disable lim, but when, as at Grarelotte, with arms of pri men were swept down in ten minutes, it is absolutely necessary, if we timely succour to the wounded, that it must be giren where they $f:$ they fall. And therefore it is that the Bearer-Company Organizat Regimental Stretcher Organization hare corne so prominently to the fr wars. It is rery little use haring magnificent base hospitals with eres il is rers little use laring eren hospitals in the front splendidly equ wounded on the field are allowed to bleed to death and sink before tl these hospitals. Therefore, $Y$ think, in view of strengthening in erery this first aid bearer-company system, that Surgeon-Major Eratt's propo militia and rolunteer reserro of bearers and of men who can be empl lospitals, a rers important one. I think I know something of field ho zation from a great deal I hare had recently to do with these mattc know probably as much as almost any one of the detail of these hos: must say I think a rast deal has jet to be done to make them efficient. can make out, a great deal is now being done, and will shortly' be make them more effieient; and I feel confident that there is erery , purt of the heads of the militars departments to strengthen and 0 hospitals so as to make them thoroughly efleient in erery possible way lope, if we should bofore long or in the near future be engaged in wal inprosement will be found to have been made both in the organizatio ment of ficld hospitals and bearer-companies.

Lieutenant-General Lord CnEIXsFord, G.C.B. : Mr. Chairman an as one of the few military Officers here present to-day, I felt it woulc I abstained from saying a few words, to express to Surgeon-Major $\mathrm{E}_{\mathrm{F}}$ here present how thoroughly I myself, and, I beliere, ereryone in th rally, have been interested in the lecture that has just becn giren. I feeling that the charge of want of interest in the subject-matter of $t$. the part of regimental Offeers cannot be gainsaid when looking a bencbes, which I regret to see on an occasion when we haro before us so much importance. I think that those who hare considered th medical treatment in the field will agree with Surgeon-Major $\mathrm{Er}$ position of the IIedical Department at the present moment is not suffic At the same time, I cannot understand how anybody can auppose for that the General commanding troops in the field is not responsible for of erery portion of his command, whether it be commiseariat, wheth port, whether it be the medical, or whether it be the combatant porti Major Eratt, howerer, who has come lately from the experience of campaign, would seem to be under that impression as regards hi: of the Service. With regard to the complaint which he makes to want of transport for the medical department during the Egrpt I am afraid he is not alone in that respect. We hear of similar compl the commissariat and other portions of the force that their wants were not attended to. If we look back to discorer who are real for this serious want, it must, I think, be laid on the country at I sented by the Gorernment, whether Conserrative or Liberal. Bo 


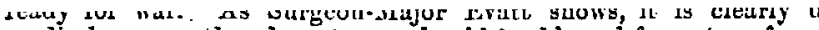
medical or nny other department should be blamed for not perform efliciently, when they are not provided with the proper means of not feel inclined to enter into the rexed question of the abolition of medical system, but I know a great many Oficers consider that a $\mathrm{g}$ been done to the Army by that step. I confess, as a former Comma was very sorry indeed to see the regimental system completely broke of reform is, that when jou find a tree not doing quite as well as $y$ should not at once cut it down and try to replace it by another, endearour by changes in the mode of treatment, by pruning he there, to see whether you really cannot make it grow up strong and 1 start by destroying a sjstem entirely, and by trying to build up a one in its place, you must expect just as has occurred in the Mfedi that it will not work smoothly, there will be frietions and diffeulties difficult to remore. I quite admit that the contintance of the regi as it existed in the Crimea, was an impossibility, and Surgeon-: perfectly right in pointing out how utterly inadequate it whs for th which we then entered. I hare also reason to beliero that the $\mathrm{pr}$ fairly treated, can be made all that the lecturer desires. Mut there

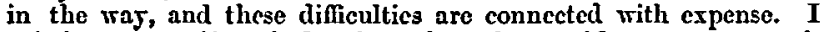
existing system, if worked as it ought to be, would prore so expensiv we may agree theoretically with what Dr. Kratt has laid down to be efticiency, howerer sanguine he maj be as to what is likely to be dc and many failures may be required before an adequate amount of to cnable that proper training and effieiency to be carried out in pc the lecturer lays so much stress upon. I think the Army is grea Surgeon-Major Evatt for laring boldly and fearlessly brought forv ment against the working of the present system, and for haring shi and powerful a way the rery great and serious shorteomings that a in our Arms Medical Department. I only trust that his hopes $\mathrm{m}$ and that those in authority who hold the purse-strings, and who ba carry out what he has recommended, may see their way to do sc special training for war which is required for the Medical Depa carried out with as much care and attention to detail as that of portions of our Army.

Dr. J. W. TAYLOR: Mr. President, I came to-day in the hope of the past experiences of a great many medical men who had served ir paigns. I must say, like Lord Chelmsford, I am somewhat disap apathy (as shown by these scantily filled benches) of our own pre particular matter; and I think that the weakmess of Surgeon-3Iajor consists in the want of combination in the rhole of the medical me but military, in not making their roices heard, so that the country pelled to expend the necessary money, which hitherto has been witl service. No doubt one of the causes of our weakness is that medi pull together as they should do; they get divided in their opinion, is the case, fou cannot monder that dificulties arise. I gather from Eratt's paper that he wishes to haro an equalizntion of force or stre eay, that if the commissariat and transport can hare their proper nur and orderlies, so he rery fairly puts before you to-day the point th branch of the Serrice should also hare its equalization of Officers an There can be no doubt about that as a matter of fairness. Then con of finance; money has to be expended, and we know rery well directl grant is asked for there is an outery, as Lord Chelmsford has sait Conserratire or Liberal Government, that so much money is being : the medical men hare done very well so far and nust get on as be: liave bad the honour of being surgcon to a rolunteer force for some and have taken very great intercst in the formation of ambulance co: companies. I think our own was one of the first in the north 
On that occasion all the difterene pattalion surgeons wese tusu all Medical Service mould be provided with ambulance conrejances for th any men who should fall out. We wero on parade at linaresmirc, $n$ know, is a large open tract of country, with our backs to the sun, a hard day's work, and we had not been standing long in that pc in one brigade alone no less than eighteen men fell out, probably frr fatigue. There was not a single arubulance, there was not a single str ground prorided by the Arny Medical Department; there was not a : lance wagon to conrer any one of those men off the ground, and the tree or anything to slielter them. We did the best we could to extemy by means of muskets and coats and such things as we could get, anc were all marching off the field about one hour afterwards, an old cab on to the ground to represent the Army hospital wagon of the Norther determined from that moment that there should be no accident of that anain to ny own battalion, and I zet to rork at once to form ambul nents in my own regiment, and first of all to nake myself cfficient b: essmination required by the Army Medical Serrice, in accordance wit lions from the War Ollice; and we now have, not only in my own di round us, growing up ambulance detachments, two men being take company. Now there are considerable difficulties in worhing this, anc point I want more specially to speak. You are arrare that formerly, lions were consolidated, we had administrative battalions, and probabl: or village we should only hare one company of men. Now it wou imposible to take tro men from a company and drill those men, bec not form a detachment; we must hare four men for a detachment. It to take two men from one village and two men from another, and for detachments for the purpose of drill. The result is, the whole of tl consolidated battalions hare to be taken from that town which possess number of men. The expenses of working this hare to be borne either by iteclf, if it can afford it, or by the medieal Officer of the battalion w take that interest in his work. Many battalions are not rery rich, and for work is certainly not rery great when the battalion surgeon is e haring to pay something like 35 l. or 40 . out of his orn pocket for the lis own ambulance corps. But the grierance docs not end there. No: get into camp than your rolunteers, your ambulance bearers, cease to medical Officer. According to the Volunteer Regulations, every $T_{1}$ properly must make himself efficient as a roluntecr in order to obtain grant, and no sooner does the medical Officer get into camp than 1 : bearers are taken from him, and they are permitted only by the sa: Commanding Officer to march past in the rear of the battalion on the । tion. Thes have no opportunity, sare bs the permission of the Comm of Adjutant, to drill, and you can easily imagine that men are rery out and do more work than is really necessary; and after they har day's drill in the field, they do not like to turn out and do ambulanes They say, in addition to that, " $W_{e}$ belong to no one, haring two se perform." Now if wo could hare a separate ambulance corps, with th similarly to those of the Army Hospital Corps; to let them hare a d they shall be known as bearers, and let them be under the comma subject to the Commanding Officer) of the principal medical Officer of 1 I am perfectly certain that, with some Gorernment aid, there would $\mathrm{b}$ whaterer in getting up a rery large army of willing and efficient beare the country, from whom could be drafted in any future war men able go abroad and ecre, who hare been trained, who have their certifies Red Cross badge, and who are quite as able to discharge their dutie:

1 At the same time permitting the capitation grant to be giren fo: bearers, instead of efficiency as marksmen, \&c. 
diffeulties to contend with. Medical men do not always feel spending money out of their onn pockets coin amore, but they $w$ recognition of what they do, and to feel that their men, when out with them in camp, shall be of some serrice. Theso are diffici contend with, and I am rery glad to have had the opportunity of co and hearing the paper which has been read to us, and offering thes your.

Captain O'Csllagrax, Iate 16th Regiment: I rise, Sir, with c dence, to make a few remarks on one point in the paper which has jus diflidence arises from $\mathrm{my}$ seeing here some more experienced and qua the subject than $I \mathrm{am}$. The main object of that paper appears to trast the present, or unified, system of the Mledical Department wit regirnental, system; and in doing this, the former system hus, I $t$ : what hardly dealt with. The defects of the Jedical Department, $v$ ficld in the Crimea, liave been clearly laid before us ; but some of th be attributed to our unpreparedness for war, and not to the fact th: regimental. We had a virid description of the surgeon of the 41 th. of the dlma, unassisted and almost alone, to deal with hundr Russians; but had Dr. Thompson worn the uniform of the medica' that of the 4 fth, would he have been able to attend to one more $\mathrm{R}_{1}$ belonged to the medical stalf, instead of to a regiment, would that $l_{1}$ with assistants and medical comforts, and with those appliances whi provided for the Army? While thero is reason to beliero that the Officers of the Army-I. may say the rast majority-ricw with appearance of the regimental system, and would gladly see it res of them would adrosite going baek to the defeets which then exi: want of field hospitals, and which were not necessarily inrolred is system.

Dr. Farquinarsox: I do not rise for the purpose of making discuss the rery interesting, graphie, and cloquent paper which Eratt has just'read to us, a paper so full of detail that I think attempt to discuss it in any proper sense without very careful stud It may disappoint him that more of us who are here have not take the interesting asstem, perlaps somewliat Ltopian, which he has $u_{z}$, but the reason simply is that it is so elaborate and so carefull we should require to consider it rery fully before speaking upon it. do is to make one or two remarks on the subject which has alread. by my friend Inspector-General Lawson, and others regarding our mental as opposed to the unification system. No one would want 1 old plan which broke down so completely in the Crimea, but this tion system has now been on its trial for ten jears, and $I$ think $w$ altogether to disregarl the opinions of the military departments $u$ If you read the Blue Book issued by Lord Morley's Commission, $y$ almost crery Commanding Officer of large camps ns well as o entirely unanimous in saying that the way in which tho unificatio worked is uncomfortable, and indeed often disastrous in its effects that the Oficers do not know whom to go to for medical attenda manding Officer does not know whom to appls to for information : of his men, and altogether there is a condition of confusion wl little care and arrangement be casily onough remorcd. I think $t$ doubt that the unification system as now carried out works badly $f$ Officer, because it withdraws him from the possibility of sharing $t$ tages which he used to enjoy in former dass in connection with his I think, it operates disadrantageously also in a professional sense, certain number of medical Oficers are attached to the large hos also a certain number who hare no connection whaterer with th therefore they hare no opportunity of sceing or attending any am 


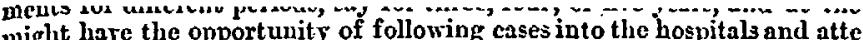
there, a plan which is well known in rural districts in the case of cottag in wbich medical men outside who send in their cases are enabled to 1 up, and attend them whilst in the hospital. That would keep up the interest of the medieal man in the men under his charge, and wou'd mutual interest between the Commanding Oflicer and the doctor tbat well for the Serrice at large. I do not see that there would be any frit been mentioned between the two classes of medical Officers, those on di regiments and thoso in the hospitals, and I do not sce that another obje lias been put forward, namcly, that the medical Officer might not $\mathrm{d}$ properly with the regiment and then go on to the hospital, holds good. days when $I$ had the honour of serring in the Guards, we simply did our duties in the morning at $80^{\prime}$ 'clock, and haring finished those, we then $v$ hospital and did our duty there. We then came back to the barrac whaterer other duts might be waiting for us. In this may our two sol ran actually together on all fours. Of course all this question means c this as laid down by Lord Merles's Commission would not be very think in the result would make the Service more attractive to medical think if the Army hopes to get the best blood from the medical schools sary to go back in some way to the regimental system, in order that, $i$ which is rery badly paid, some superior social adrantages may be offer pensate for tolerably hard work and bad pay.

Mr.J. FurLeY : I had no ambition, Sir, to swell the category of tho verbially rush in where angels fear to tread, and I certainly had no $j$ addressing this meeting to-daj; but perhaps I may be allowed to mak upon the concluding paragraphs of Surgeon-Major livatt's paper. I roluntecrs hare already spoken on the subject, and I remember when I nu actire Officer of rolunteers, I used to think it was an absurdity to ca in arms, sceing that we had no regular medical department and $n$ serrice, a position which has been so well deseribed hy Dr. 'Taylor; bu that I afterwards saw reason to change my opinion irrespectire of the expense that Commanding Offers and others connected with rolunte bear. I thought that as wo were nerer to be called out of the countr no necessity for an expensire medical department or for an expensir system, for should we unfortunately be engaged in defending our countr. be backed up by all the civil hospitals and nursing establishments, and i societies as the Red Cross, and the St. John's Ambulance Association, fore that a complete medical department was not necessary. Command: of rolunteers are alwajs rery much disinclined to lose even a single file and there were many otber reasons against a distinct department. events have shorn that the Army MIedical Department is in need of a in time of war. Surgeon-3rajor Eratt has referred to a new ambulan tion that has been started in eome of the London hospitals, composed students. The instruction that these gentlemen are so willingly undere present moment is of the most raluable description, whether their futur civil or military. At the same time, they are much too raluable to be ] position of sick-bearers, and we must add to that organization, if it is $t$ real adrantage, a large class of useful men of lower social degrec. I h slightest doubt from my own experience that we should be able in a time to.find plenty of men who would readily join those gentlemen, and a really important crganization to supplement the Army Mfedical Dep caec of war. I do hopo that this new association will rery soon hare $t$ ] tion of the War Ofice and the support of the Arms Medical Deparim the same capitation grant be given to tho members as is allowed to rolur rally, and if the hope bo held out to them that in case of war their serv utilized, and they will receive pay, then, I think, this much needed : will readily be found should it be wanted. 
sugestions that hare been introduced into Surgen- sume renars: the most important are the additions which he proposes to $n$ hospitals, and the manner in which he proposcs to obtain reserres $i$ the bearer-companies and for the field hospitals. I bardly think $t]$ sufficiently referred to all that has been done on these subjects to I deal of consideration has been given. They were very fully discus which was furnished by Colonel Bractenbury, Major Kenmis, an organization of the medical services of different Continental armies the appliances at the Brussels Sanitary Exhibition of 1876 , and $b$ the formation of which that Report subsequently led to, that orgar companies and field hospitals of which the constitution and $c$ embodied and described in the Army Medical Regulations of 18 that the recommendations of that Committee, so far as regards obta the bearers of the bearer-companies, will be found sufficient efficient. I will, with jour permission, read a short extract $f$ respecting the tables of the bearer-companies and field hosp following:-"The tables of the bearer-companics and field hospi number of men as lospital attendants drawn from reserves. "I Corps at present cannot supply such a reserre. As these men arc for fatigue duties, as distinguished from shilled attendants $c$ Committce recommend that a proportion of the Army Hospital enlisted for as short a service with their companies as is compa instruction in these duties, and be then for the remainder of $t$ passed into the First Class Army Rescrve. Until the corps is supplement its companies by such reserves they consider it des: should be taken for detailing the number necessary for one or two the militis reserres." It is a rery important matter, and $I$ there to allude to it, that we should hare exact notions regarding the d reserre men qualified to act $3 s$ bearers, and to do the fatigue $d$ companies and feld hospitals, and reserre men, who are qualified to the wards of the hospitals, to take the place of the hospital ord latter are remored from the hospitals at home to proceed on foreig the duties which they are called upon to perform in time of war. difficulty, I anticipate, in getting sufficient reserre men who. arailable for doing hospitol fatigue duties and the duties of bear with which can readily be acquired in from three to four weel anticipate that the plan proposed of a militia hospital corps re hospital attendants can be carried into exceution without great di such attendants as are competent to take the place of the regula Corps men for nursing the sick when the ordinary establishm increased to what is necessary for meeting the wants of a time of $w$. must be composed of trained and sufficiently esperienced men got $f$ the Army IIospital Corps itself. We had some experience on thi on the oceurrence of the Egyptian campaign when all the hospital remored from Netley in order to make up the establishment for $t$ l and bearer-companies proceeding to Fgypt. At first we had a nur from the ranlis of the regiments at Porismouth to take their place we had men from the reserves dressed as Army Hospital Corps limited amount of traicing as bearers, who took the place of the re the wards. The surgeons much preferred the reginental men w] knowing anything of the duties of Army IIospital Corps men, but part were disciplined, obedient, and tractable, and who in many great deal of interest in the ward work, to the reserre men who $r$ Irmy Hospital Corps men after threc or four weeks' training in Aldershot. We had the greatest difficulty with these latter men, 0 drunken habits and apparent dislike to the ward duties. Had t fatigue men to do fatigue duties, or eren to act as bearers after $t$ had had for a few weeks at Aldersliot, they would no doubt 1 
increment that Dr. Eratt proposes to the field hospitals, I cannot this as quite such an eass thing as he describes; it seems to me, on the vers serious and difficult matter. Dr. Eratt is proposing to increase th ment nearly two-thirds orer the present establishment in each fiel Jiultiply that by twenty-fire, the number of field hospitals for one army seo what a rast increase of men it is that is asked for to be trained, ratio after, and paid. And it is also a matter for grave consideration whetl increment as this can be held to be necessary. Some increase of estab rerards attendants $i_{3}, I$ believe, admitted to be necessary by all, but wher a British hospital with an Indian hospital, we must alwajs remembe large establishment of hospital serrants in India is partly due to caste just as our own prirate establishments of serrants in India have to be increased in number from the same cause. Again, with regard to $s$ particular servants mentioned, those for the conservancs arrangement: supply, the washing, and so on, we must recollect that the Commi Transport Department is at present responsible for executing these du field. We can hardly expect, therefore, to hare independently a sufficier ment to be able to do all these things entirely ourselres. Practically in field hospitals are generally supplemented by a certain number of men $t$ fatigue duties. Somo of them were so assisted in EgJpt, I belier number of men, Egyptian prisoners, muletecrs, and others, being sent to $t$ for screice in rarious capacities. It lias always been understood that tl are to hare the adrantago of men extra to tho fired establishments be them when needed to do fatigue duties. That wo can oblain a fixed fic establishment as is represented in the table before us under present cir seems to me rery problematical. But, howerer, without entering mo these and some other topies that might be enlarged upon, I may say that I bare the fullest reliance, and I feel sure ercryone at this meeting I hare full reliance, that all the topies which Dr. Evatt has so cloquently bro us to day will be very thoroughly considered by the responsible head o Medical Department. We hare at the head of our Service an Offic sagacity, who has had for many geurs to consider and to carrs out pr: organization of our war bospital establishments, not only in this count in India, and who, as a member of Lord Morley's Comnittee, must ha man of the subjects discussed to-day already brought under his conside has also uround him a staff of rery able practical men to assist him We may infer also, from the exhaustive inquiries that hare been insti the direction of the War Department, that the authorities there are : necessity of continuing to add to the efficiency of the medical serrice, a will be done by them, as well as by the military anthorities (who, of c the welfare of the sick and wouncled troops just as much at heart : whaterer different riews mas be entertained as to the manner in which । carried out), to place our ticld hospital establislıments on as complete a a basis as possible. From all these circumstances together we may re: that the important matters brought before us by Dr. Eratt, as well : expressed by the rarious Offeers and others who hare faroured us opinions to-day, will be taken into very full consideration, and may nc left in the hands of the authorities who alone hare the power to bring pructical issue.

Surgeon-JIajor Evatr, in replying, said : I hare but a ferr words to $s$ As to Surgeon-General Lawson's allusion to the fact that general hospi in our old wars, I am of course aware of that. But what were those They were completely without organization, and were in the last ce: charnel-houses. You can call them nothing else; for without medice trained subordinates you cannot have real elliciency. As to the rolunter feel certain we have a large field there, from whence, if we trs, we can c war help; but we need to train them in peace for war, and not to wai 
milititin reserre, and sent into the hospitals without any training judge of militin help by such men would be quite wrong; and it is confusion that I propose to train regularly a militia reserve for or and not wait until war comes, and then rush thom into our hospi untrained. I want to see a regular Militia Hospital Corps called or trained with $u 3$ in the hospitals, instead of being kept at infan barracks. We need such a bodr of men to work our home hospital: well as to furnish the coarser aid in the war hospitals. During war to great striits at home for men for our hospitals, and we har combatant soldiers from their clrills and their regular mork to assist injuriously in two ways - the men are inefficient as nurses, and they from their omn special work outside. $A s$ to the question of rate needed in India on account of caste, I do not think that this is the ct water-pipes Iaid on to $\mathrm{mr}$ house at Woolwich, $\mathrm{I}$, too, in England shoul man to carry water for the domestic service of my house. In India supply laid on, and hence, caste or no easte, we need watermen. Inc. years behind London in cirilization, and war is practically a return 1 saragery of the world when all the subsidiary serrices of a house $h$ by human agency. Sewage is remored in Ingland by drains; $i$ human agener. A dhobie exists in India to wash clothes, but pra dhobies in Fngland, only they mork in laundrics organized for many families, and hence we do not see them so prominently befi theless they do exist; and as in war jou hate no laundries, jou to tho primitire washerman of an earlier time. It is in no sense a it is simply a return to primitire conditions. ds regards the aiming the Director-General and by the whole of the War Office officials of er questions for a moment low ardently they hope to obtain complete For one hundred ycars the doctors hare written, and spoken, nn complete war efficiency, but it really is not possible to obtain it wit the public as to what is needed. IIowever strong may be the desire, General or the Commander-in-Chief to achiere erersthing we need fo be possible to obtain the money needed for these things unless public $o_{1}$ up to the standard that will make the House of Commons rote what need as it were a band of missionaries of the Red Cross to go out an crusade, and teach the people what we need. When they know then, and only then, will they giro it to ns. The people of Englan payers talk about humauity; let them, howerer, do their shar humanity also.

The Crampax : I have now the tery pleasant duty of asking your thanks to Surgeon-JInjor Evatt for his very interesting and sug which thanks I am sure jou will fully agree with me he richly deser 